\title{
Sid \\ First report of Rice stripe necrosis virus infecting rice in Sierra Leone
}

M.J. Tucker ${ }^{1} *$, M.G. Celli ${ }^{2,3}$, A.B. Conteh ${ }^{1}$, D.R. Taylor ${ }^{1}$, E. Hébrard ${ }^{3}$ and N. Poulicard ${ }^{3}$

${ }^{1}$ RARC, SLARI, Rokupr, PMB 736, Freetown, Sierra Leone ; ${ }^{2}$ IPAVE-CIAP-INTA, km 5 1/2, Camino 60 Cuadras, Córdoba, Argentina ; ${ }^{3}$ IRD, Cirad, University of Montpellier, IPME, 911 Avenue Agropolis, 34394 Montpellier, France

*E-mail: nils.poulicard@ird.fr

Received: 10 Jan 2020. Published: 29 Jan 2020. Keywords: Oryza sativa

While Rice stripe necrosis virus (RSNV, Benyvirus, Benyviridae) has been reported on rice plants on two continents, little is known about the diversity of this multipartite virus which is transmitted by the plasmodiophorid protist Polymyxa graminis. First identified in 1983 in the Côte d'Ivoire (Fauquet \& Thouvenel, 1983), the disease had previously been observed in Sierra Leone without formal identification of the causal agent (Buddenhagen, pers. comm.). Later, the virus was reported in South and Central America (Colombia, Ecuador, Panama and Brazil) causing up to $40 \%$ yield losses (Morales et al., 1999). Recently, RSNV was identified for the first time in several African countries including Burkina Faso (Sérémé et al., 2014), Benin (Oludare et al., 2015) and Mali (Decroës et al., 2017) suggesting a re-emergence of the virus in Africa.

In 2019, symptoms of leaf-crinkling and stripe necrosis were observed on a rice plant from the Bo District in Sierra Leone (Fig. 1). Leaf samples were analysed by serological and molecular methods to confirm the presence of RSNV in Sierra Leone. RSNV was detected by plate-trapped antibody (PTA)- ELISA using a polyclonal antiserum against RSNV (Fauquet \& Thouvenel, 1983).

The presence of the virus was confirmed after total RNA extraction using $0.05 \mathrm{~g}$ of leaves and the RNeasy Plant Mini Kit (Qiagen) and RT-PCR amplification (10 U/ul M-MLV-reverse transcriptase, Promega; $10 \mathrm{U} / \mu \mathrm{l}$ Dynazyme, Finnzyme) as described previously (Sérémé et al., 2014, Oludare et al., 2015) with primers RSNV1-2901F 5'-TGAATTTGGTGCTCTCTTG-3' / RSNV1-3827R 5'-TGTGGCGTTTCCAGACCTAAA-3' and RSNV2-5' 5'-TATCACTACTGACGAATTCCACCTAC-3' / RSNV2-1223R 5'-AATCTGCGGCCTGTTTTGTA-3'. Specific amplicons, 926 and 1241 nt in length, were generated corresponding to sequences in the helicase domain and the coat protein (CP) genes on RSNV RNA 1 and RNA 2, respectively. The amplicons were sequenced directly and the sequences deposited in GenBank (Accession Nos. MN750254 and MN750255, respectively)

The helicase sequence obtained from the Sierra Leone RSNV isolate showed 1.8-7.3\% genetic distance with those from South America (EU099844.3, MG792544, MG792545, MG792546) and only 1.4-2.2\% with those from Africa (KP099623, MF115599, MF115600, MF115601, MF115602, MF115603, MK170452, MK170453). The phylogenetic analysis based on the helicase domain included the sequence obtained from the Sierra Leone within a cluster represented by RSNV from South America and West Africa (Fig. 2a). In contrast, the CP sequence from the Sierra Leone RSNV isolate revealed an unexpected genetic differentiation as compared to all the other sequences from South America (5.6\%; NC_038774) or Africa (5.2-6.5\%; LK023710, MF115604, MF115605,

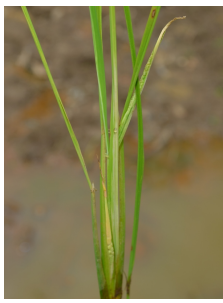

Figure 1

To cite this report: Tucker MJ, Celli MG, Conteh AB, Taylor DR, Hébrard E, Poulicard N, 2020. First report of Rice stripe necrosis virus infecting rice in Sierra Leone. New Disease Reports 41, 10. http://dx.doi.org/10.5197/j.2044-0588.2020.041.010

(c) 2020 The Authors

This report was published on-line at www.ndrs.org.uk where high quality versions of the figures can be found.
MF115606, MF115607, MF115608, MK170454, MK170455). Interestingly, the $\mathrm{CP}$ sequence from Sierra Leone is located at a basal position in the phylogeny (Fig. 2b)

To our knowledge, this is the first confirmed report of RSNV in Sierra Leone. Further studies are needed to assess the molecular and biological diversity of RSNV, the spatial distribution and the incidence of this reemerging rice disease in Africa.

\section{Acknowledgements}

Drs. Tucker and Celli contributed equally as first authors of this report. This work was funded by the French National Research Agency (ANR-10-LABX-001-01) / Agropolis Foundation (1504-004).

\section{References}

1. Decroës A, Bagayoko I, Mahillon M, Verhaegen H, Liénard C, Legrève A, Bragard C, 2017. Detection of the Rice stripe necrosis virus causing rice crinkle disease and its vector Polymyxa graminis f. sp. colombiana in Mali. Plant Disease 12, 2155. http://dx.doi.org/10.1094/PDIS-06-17-0801-PDN

2. Fauquet, CM, Thouvenel, JC, 1983. Association d'un nouveau virus en bâtonnet avec la maladie de la nécrose a rayures du riz en Côte d'Ivoire. Comptes Rendus de l'Académie des Sciences Serie D 296, 575-578.

3. Maurino MF, Giménez Pecci MP, Kruger RD, Cúndom MA, Gutierrez SA, Celli MG, 2018. First report of Rice stripe necrosis virus in Argentina. Crop Protection 114, 143-147. http://dx.doi.org/10.1016/j.cropro.2018.08.012

4. Morales FJ, Ward E, Castaño M, Arroyave JA, Lozano I, Adams MJ, 1999. Emergence and partial characterization of Rice stripe necrosis virus and its fungus vector in South America. European Journal of Plant Pathology 105, 643-650. http://dx.doi.org/10.1023/A:1008786832634

5. Oludare A, Sow M, Afolabi O, Pinel-Galzi A, Hébrard E, Silué D, 2015. First report of Rice stripe necrosis virus infecting rice in Benin. Plant Disease 99, 735. http://dx.doi.org/10.1094/PDIS-11-14-1126-PDN

6. Sereme D, Neya BJ, Bangratz M, Brugidou C, Quedraogo I, 2014. First report of Rice stripe necrosis virus infecting rice in Burkina Faso. Plant Disease 98, 1451. http://dx.doi.org/10.1094/PDIS-06-14-0626-PDN

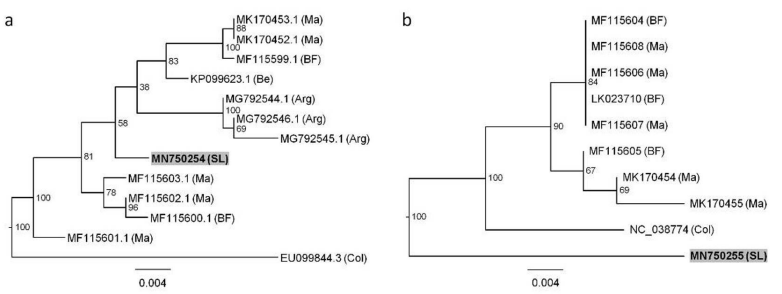

Figure 2 